\title{
RAPD Markers Linked to Late Blight Resistance in Tomato
}

\author{
Bal K. Joshi1 ${ }^{*}$, Dilip R. Panthee ${ }^{2}$, Frank J. Louws ${ }^{3}$, G. Craig Yencho ${ }^{2}$, Bryon Sosinski ${ }^{2}$ \\ and Consuelo Arellano ${ }^{4}$ \\ ${ }^{1}$ Genebank, Nepal Agricultural Research Council, Khumaltar, Lalitpur \\ ${ }^{2}$ Department of Horticulture \\ ${ }^{3}$ Department of Plant Pathology and \\ ${ }^{4}$ Department of Statistics, North Carolina State University, NC \\ e-mail: joshibalak@yahoo.com
}

\begin{abstract}
Identification of marker is the prerequisite for marker assisted selection (MAS) and is also very effective for gene pyramiding. Bulked Segregant Analysis (BSA) technique was used to identify RAPD markers linked to the late blight disease (caused by Phytopthora infestans (Mont. de Bary) resistance in tomato using $\mathrm{F}_{2}$ population generated by crossing tomato inbred lines, NC 85L-1W(2007) which is resistant to late blight and NC 839-2(2007)-1 which is susceptible to it. A total of $250 \mathrm{~F}_{2}$ plants, and 10 plants each of the parents and $\mathrm{F}_{1}$ were used for BSA. Transgressive segregation was observed for late blight resistance. The segregation of susceptible and resistance perfectly fit the expected ratio of 3:1, that means resistance is governed by single recessive gene. Only 34 RAPD primers (17.26\%) were found polymorphic between parents. Sixteen RAPD primers (47\%) out of 34 gave polymorphic bands between resistant and susceptible bulks of the late blight. Four RAPD primers, namely MRTOMR-026, MRTOMR-031, MRTOMR-038 and MRTOMR-046 were identified as linked markers to loci related to late blight disease. Among those, two were linked to susceptible and two to resistance. Because of low reproducibility and dominant nature of RAPD, these markers need to be converted to SCAR markers.
\end{abstract}

Key words: bulked segregant analysis, resistant bulk, susceptible bulk, Solanum lycopersicum

\section{Introduction}

Tomato (Solanum lycopersicum L., $2 \mathrm{n}=2 \mathrm{x}=24$ ) is a tropical vegetable and used both as fresh and processed form. It is the second most consumed vegetables after potato in the world (FAOSTAT 2010). Breeding efforts of tomato have been focused mainly on fruit yield and foliar diseases. The most important foliar disease of tomato is the late blight (Panthee \& Chen 2010) caused by Phytopthora infestans (Mont.) de Bary, which can destroy tomato field within few days of infestation (Fry \& Goodwin 1997) in conducive environment for the pathogen development. The most conducive environment for the disease development is wet and cloudy weather with cool temperature. Airborne nature of the pathogen helps to spread out in a larger area quickly. Late blight is the eighth most serious diseases of tomato in terms of crop loss per acre in USA (Davis et al. 2000). Advances have been made on resistance breeding to combat this disease in tomato (Foolad et al. 2008). Both vertical and horizontal resistances have been reported in tomato. Single dominant resistance gene $(R)$ to late blight is commonly found in wild species. Four race specific $\mathrm{R}$ genes, $P h-1, P h-2, P h-3$ and $P h-5$ conferring resistance to it have been identified in Solanum pimpinellifolium. $P h-1$ is a completely dominant gene, identified in $S$. pimpinellifolium and mapped to the distal end of the chromosome 7 (Foolad et al. 2008). LA-3707, a selection of $S$. pimpinellifolium from Asian Vegetable Research and Development Center (AVRDC), contributed the $P h-3$ gene, and Richter's Wild Tomato was the source of a partially dominant gene, $\mathrm{Ph}$-2 (Gardner \& Panthee 2010b). $P h$-2 gene was mapped in the chromosome 10 . The $P h-3$, another partially dominant gene is more 
durable than $P h-1$ and $P h-2$. The newly identified R gene, $P h-5$ was found superior to all the other $\mathrm{R}$ genes for late blight (Foolad et al. 2008). Quantitative trait loci (QTLs) have also been identified from the population developed by crossing cultivated tomato with wild tomatoes (Brouwer et al. 2004).

A few resistant varieties of tomato have been developed through the introgression of resistant genes either from cultivated or from wild species of tomato (Panthee \& Gardner 2010, Gardner \& Panthee 2010a). However, these varieties may not be adaptable to all tomato growing regions and the resistance may not be long lasting. Therefore, research towards the development of new resistant varieties is being continuously undertaken. More than eight years is required to develop a resistant variety through conventional breeding i.e. by using phenotypic selection. Molecular markers have now become a very useful tool for breeders to select the desirable genotypes. Molecular markers are useful for accelerating the breeding works more precisely with efficient selection. Markers linked to the gene(s) of interest, help to select plants genotypically that are genetically similar to the recurrent parents possessing the desired traits. However, due to the unavailability of PCR-based molecular markers tightly linked to late blight resistance, marker assisted selection (MAS) has not been in routine in late blight resistance breeding. Identification of linked marker(s) is the prerequisite for MAS and is also very effective for gene pyramiding.

Earlier, use of near isogenic lines (NIL) was the common means of identifying genes of interest. NIL are not available for most of the target regions and it takes long time to develop NILs. Alternatively, Michelmore et al. (1991) developed a very rapid and simple PCR based method to identify the gene of interest called BSA and identified RAPD markers linked to a disease resistant genes in lettuce. For BSA, any kind of mapping populations e.g. Recombinant Inbred Lines (RIL), Backcross (BC), $\mathrm{F}_{2}$ or Double Haploid (DH) that are segregating for a trait of interest can be used. For dominant marker, e.g. RAPD, the $\mathrm{F}_{2}$ population is considered best, because of the double number of segregating loci in $\mathrm{F}_{2}$ than in the BC (Mackay \& Caligari 2000).

In BSA, two extreme phenotypes, i.e. low and high of a particular trait (e.g. resistance and susceptible) from a segregating population are compared using bulk DNA from these two contrasting individuals. DNA from individuals similar in trait of interest are bulked and assumed that the bulks are homozygous for the targeted loci and heterozygous for the rest of the loci (Giovannoni et al. 1991, Michelmore et al. 1991, Quarrie et al. 1999). DNA markers are then used to screen the parents and the bulks. If polymorphism is found between bulks, this marker (polymorphic band) is expected to be associated with gene of interest.

Many disease resistance genes have been identified in tomato using random amplified polymorphic DNA (RAPD) following the BSA approach (Stevens et al. 1995, Chagué et al. 1996, De Giovanni et al. 2004). Once it is identified, this marker is then converted into co-dominant markers, such as cleaved amplified polymorphic sequence (CAPS), sequence characterized amplified region (SCAR) which are more reliable than RAPDs. Chunwongse et al. (2002) identified the Amplified Fragment Length Polymorphism (AFLP) markers linked to $\mathrm{Ph}$-3 using BSA.

In this study, BSA technique was used to identify RAPD markers linked to late blight resistance in tomato using $\mathrm{F}_{2}$ population. An $\mathrm{F}_{2}$ population is the earliest segregating generation available for mapping genes from the crosses and provides the greatest genetic window around the locus (Michelmore et al. 1991). R gene was tagged based on the segregating population that were naturally infested with late blight.

\section{Methodology}

\section{Plant materials}

Two tomato inbred lines, NC 85L-1W(2007) (referred to hereafter NC 85L) and NC 839-2(2007)-1 (referred to hereafter $\mathrm{NC} 839$ ) were crossed to produce $\mathrm{F}_{1}$ population in greenhouse. NC 85L, used as a female is resistant to late blight (resistant parent, RP) and NC 839 , used as male is susceptible to late blight (susceptible parent, SP). The $\mathrm{F}_{1}$ plants were selfed to obtain $\mathrm{F}_{2}$ seeds. A total of $250 \mathrm{~F}_{2}$ plants, and 10 plants each of RP, $S P$ and $F_{1}$ plants were grown. Nine $F_{2}$ plants were blind (deformed plants), therefore $241 \mathrm{~F}_{2}$ plants were used. The fruit of NC 85L is mini roma type with dark red fruit color (Table 1). The resistance source of late blight in NC 85L traces back to the L3707 and Ritcher's wild tomato (S. pimpinellifolium). 
Bal K. Joshi et al/RAPD Markers Linked to Late.......

Table 1. Parental description along with their pedigrees and coefficient of parentage

\begin{tabular}{|c|c|c|c|c|c|c|}
\hline Parent & Maturity & $\begin{array}{l}\text { Fruit type, } \\
\text { shape, color }\end{array}$ & $\begin{array}{l}\text { Disease } \\
\text { reaction }\end{array}$ & Pedigree & $\begin{array}{l}\text { Common } \\
\text { pedigree }\end{array}$ & COP \\
\hline $\begin{array}{l}\text { NC 85L- } \\
1 W(2007)\end{array}$ & Early & $\begin{array}{l}\text { Mini roma } \\
\text { type, dark red }\end{array}$ & $\begin{array}{l}\text { Late blight } \\
\text { resistance }\end{array}$ & $\begin{array}{l}\text { 051(x)- } \\
18 / / 0463 / 9722(\mathrm{x})-18\end{array}$ & $\begin{array}{l}\text { 0179(x)-1-18-4, } \\
215 \mathrm{E}-1(93)\end{array}$ & \\
\hline $\begin{array}{l}\text { NC 839- } \\
2(2007)-1\end{array}$ & Average & $\begin{array}{l}\text { Grape type, } \\
\text { light red }\end{array}$ & $\begin{array}{l}\text { Septoria leaf } \\
\text { spot resistance }\end{array}$ & $\begin{array}{l}051(\mathrm{x})-18 / / \mathrm{CB} 25(\mathrm{x})- \\
18-3 / 9722(\mathrm{x})- \\
18 / 0464\end{array}$ & $\begin{array}{l}\text { 9722(x)-18, 051, } \\
03220, \mathrm{L3707}\end{array}$ & 0.227 \\
\hline
\end{tabular}

COP = Coefficient of Parentage

\section{Field evaluation}

A total of 280 plants, consisting of 10 plants each of $\mathrm{RP}, \mathrm{SP}$, and $\mathrm{F}_{1}$ plants and $250 \mathrm{~F}_{2}$ plants were planted in the research plot of Mountain Horticultural Crops Research and Extension Center (MHCREC), Mills River, USA during summer, 2009. This research plot was a hot-spot for late blight and natural inocula were observed at high pressure for screening late blight segregating population in the summer of 2009. Weather condition in 2009 was favorable for disease development (Figure 1). All these plants were evaluated for resistance to late blight with natural inocula. Experimental site was in Mills River, Henderson, North Carolina, located at an altitude of $630 \mathrm{~m}$ above sea level with latitude of $35.42721^{\circ} \mathrm{N}$ and longitude of $82.55888^{\circ} \mathrm{W}$.

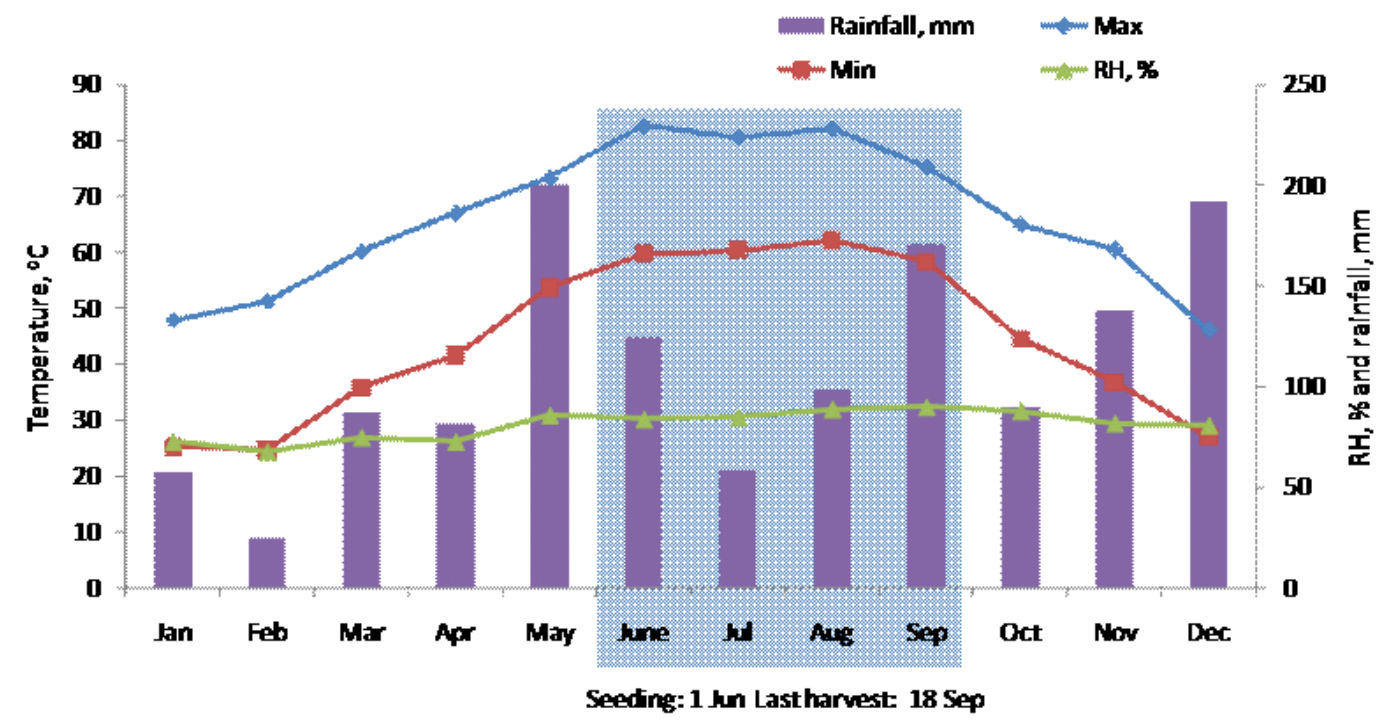

Fig. 1. Monthly weather conditions during tomato growing period (shaded area) in Mills River, North Carolina, 2009. Min = Minimum temperature $\left({ }^{\circ} \mathrm{C}\right)$, $\max =$ Maximum temperature $\left({ }^{\circ} \mathrm{C}\right), \mathrm{RH}=$ Relative humidity $(\%)$

Initially, seeding was performed on June 1, 2009 in trays $(30.5 \times 45.7) \mathrm{cm}$ containing peat moss and vermiculite. The trays were then kept in glasshouse with temperature set at $21.1^{\circ} \mathrm{C}$. Twelve days old seedlings were transplanted in a 50 -cell tray $(12.5 \mathrm{x}$ $24.4 \mathrm{~cm})$. Six-week-old seedlings were then transplanted in the field having loam type soil with row to row distance of $1.5 \mathrm{~m}$ and plant to plant distance of $45 \mathrm{~cm}$. The bed was raised and covered with black plastic. Other recommended cultural practices were followed as described in Vegetable Crop Handbook, Southern US 2010. Fruits were harvested from September 9 to 18, 2009.
DNA extraction, quantification and dilution DNA was extracted from all the individual $F_{2}$ plants, parents and $\mathrm{F}_{1}$ following the method of Fulton et al. (1995). Approximately $100 \mathrm{mg}$ of young leaves from 23 week old tomato seedlings was collected from greenhouse in $1.5 \mathrm{ml}$ Eppendorf tube. This tube was then dipped into liquid nitrogen and samples were ground by glass rod. After adding $200 \mu \mathrm{l}$ microprep buffer (Fulton et al. 1995), samples were incubated at $65^{\circ} \mathrm{C}$ water bath for about $60 \mathrm{~min}$ and chloroform/ isoamyl (24:1) solution was added (about $600 \mu \mathrm{l})$ to each tube. Samples were then centrifuged at 10,621 g for $5 \mathrm{~min}$. Aqueous phase was pipetted off into new 
micro-centrifuge tube and $2 / 3^{\text {rd }}$ times the volume of cold isopropanol was added to precipitate DNA. Samples were finally centrifuged at $10,621 \mathrm{~g}$ for 5 min and the obtained DNA pellets were washed with $70 \%$ ethanol. Dry DNA pellets were resuspended in $1 \mathrm{x}$ TE buffer (100 $\mu \mathrm{l}$, Fisher) and stored at $-20^{\circ} \mathrm{C}$. Concentration of DNA in different samples was estimated by spectrophotometer (NANO Drop 1000, Thermo Scientific, USA). Working solutions of DNA samples with a concentration of $20 \mathrm{ng} / \mu \mathrm{l}$ were prepared from the original DNA samples in 1x TE buffer.

\section{RAPD}

A total of 197 10-mer RAPD primers were screened using 20 ng DNA template of two parental lines. Primers polymorphic to parental lines were then used to screen resistant and susceptible bulks. Amplification reactions were performed in $10 \mu \mathrm{l}$ reaction volume containing $1 x$ PCR buffer (10 mM Tris-HCl pH 8.3, 50 mM KCl, $1.5 \mathrm{mM} \mathrm{MgCl}_{2}$, Fisher), $200 \mu \mathrm{M}$ each of dNTPs, $0.2 \mu \mathrm{M}$ primer and $1 \mathrm{U}$ Taq polymerase. About $15 \mu \mathrm{l}$ mineral oil was overlaid on the reaction mixture in each tube. DNA amplifications were performed in thermal cycler (Eppendorf, New York) using the following cycling condition: one cycle of $92^{\circ} \mathrm{C}$ for $3 \mathrm{~min}, 45$ cycles of $92^{\circ} \mathrm{C}$ for $60 \mathrm{sec}, 42^{\circ} \mathrm{C}$ for $1 \mathrm{~min}$ and $72^{\circ} \mathrm{C}$ for $60 \mathrm{sec}$; one cycle of $72^{\circ} \mathrm{C}$ for $8 \mathrm{~min}$ followed by holding at $4^{\circ} \mathrm{C}$.

\section{Bulked segergant analysis}

Bulked segregant analysis was done following the method of Michelmore et al. (1991). Two DNA bulks, called resistant bulk (RB) and susceptible bulk (SB) were prepared from $\mathrm{F}_{2}$ individuals. $\mathrm{RB}$ consisted of 8 individuals with disease score of 0 and SB consisted of 8 individuals with the score of 4.5 and 5. DNA was extracted separately from each individual of $F_{2}$ population. Later, DNA bulk was prepared by pooling equal volume $(50 \mu \mathrm{l})$ of DNA of each of eight resistant and susceptible $F_{2}$ plants for RAPD analysis. PCR was performed with polymorphic primer for the bulks and parental DNA samples using the same reaction condition as described above.

\section{Gel electrophoresis}

All PCR products were analyzed in 2\% Agarose gel which was mixed with $1.86 \mu$ l of ethidium bromide solution (Fisher) of $10 \mathrm{mg} / \mathrm{ml}$ concentration in $1 \mathrm{x}$ TBE buffer (40 mM Tris-borate, pH 8.0, 1 mM EDTA) with a 100-bp ladder (Fisher). Electrophoresis was performed at $135 \mathrm{~V}$ for 2 hours. Gels were rinsed with water to enhance contrast and photographed under UV light on GelDoc system.

\section{Data scoring and analysis}

Disease severity was scored on 85 day-old plants. Individual disease rating scores were based on visual assessment of symptom severity. Following scoring criteria was developed based on Winstead and Kelman (1952), Tu and Poysa (1990), Danesh et al. (1994) and used in this study:

$0=$ no disease symptoms; $0.5=$ Less than $10 \%$ leaf area with symptoms; $1=10-20 \%$ leaf area with symptoms; $1.5=20-30 \%$ leaf area with symptoms; 2 $=30-40 \%$ leaf area with symptoms; $2.5=40-50 \%$ leaf area with symptoms; $3=50-60 \%$ leaf area with symptoms; $3.5=60-70 \%$ leaf area with symptoms; 4 $=70-80 \%$ leaf area with symptoms; $4.5=80-90 \%$ leaf area with symptoms; $5=90-100 \%$ leaf area with symptoms.

Categories from 0 to 1.5 were considered resistant, from 1.5 to 3 as moderately resistant and from 3 to 5 as susceptible. For inheritance study, all these segregating plants were grouped into two, one resistant group with score from 0 to 2 and susceptible group with score from 2 to 5 . Scores of parental lines and $F_{1}$ were averaged. Frequency of $\mathrm{F}_{2}$ populations under different score categories was estimated for segregation analysis using SPSS v.17.0 (IBM Corporation, New York, USA). Skewness was estimated using SPSS v.17.0. Frequency data were analyzed by the $\chi^{2}$ to test the goodness of fit at an expected ratio of 1 resistance and 3 susceptible lines using SAS v.9.1.

The pedigrees of these two lines were traced back to estimate the coefficient of parentage (COP), which was estimated between parents based on the assumption that all ancestors and parental lines were homozygous and a line derived from a cross obtained one-half of its genes from each parent. The computer software KIN (Tinker \& Mather 1993) was used to calculate the COP. RAPD fragments were scored as 1 for presence and 0 for absence. Band size was estimated based on the 100-bp ladder 
(Bioline USA Inc, MA, USA). Simple statistics based on the DNA bands were calculated using MS Excel 2007.

\section{Results and Discussion}

\section{Disease reaction}

Frequency distribution of late blight resistance among tomato plants in $\mathrm{F}_{2}$ population is given in Figure 2.
Distribution was slightly right skewed with -0.71 skewness. Disease scores of some $\mathrm{F}_{2}$ individuals were either higher than susceptible parent or lower than resistant parent. Average score of resistant parent was 1.1 and of susceptible parent was 4.2. Transgressive segregation was observed towards resistance as well as susceptibility. This indicated that resistant parent also had some role in susceptibility and susceptible parent contributed towards resistance.

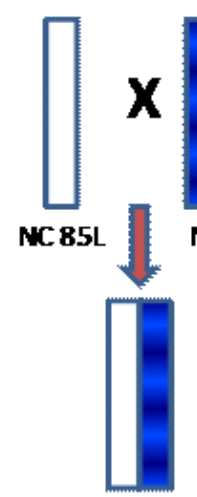

$F_{1}$
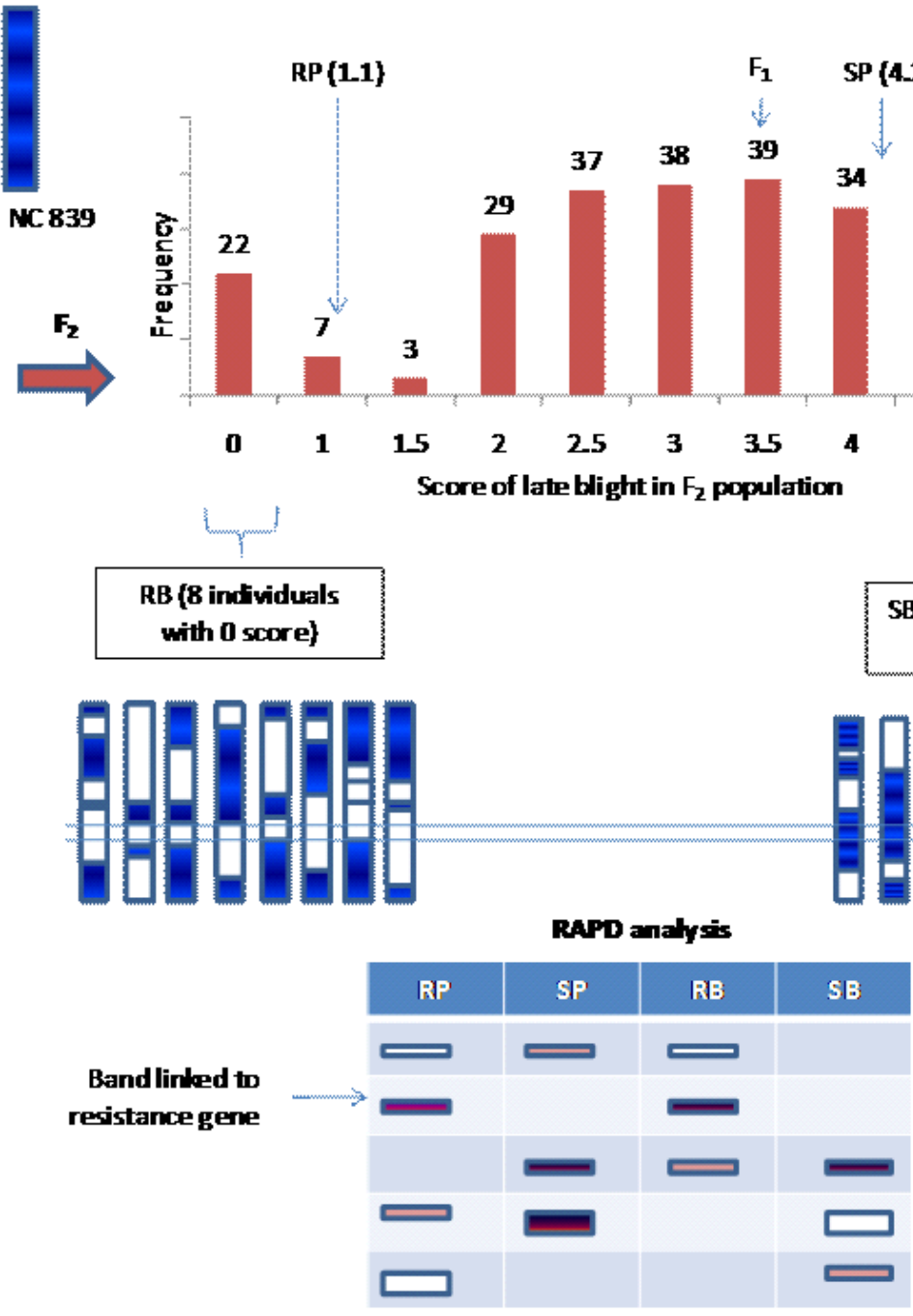

Fig. 2. Frequency distribution of $241 \mathrm{~F}_{2}$ individuals of NC 85L-1W(2007) x NC 839-2(2007) based on the score of infestation of late blight in tomato, Mills River, 2009 and bulked segregant analysis method adopted in this study and schematic representation of RAPD band linked to resistance gene. The average phenotypic values of the parents and $\mathrm{F}$ are shown by arrow. RP = late blight resistance parent, NC 85L-1W(2007). SP = late blight susceptible parent, NC 8392(2007). RB = Resistant Bulk. SB = Susceptible Bulk 
The average score of $F_{1}$ was 3.5, which indicated that the resistance was controlled by incomplete dominance. Some of $\mathrm{F}_{1}$ individuals were affected as severely as the susceptible parents. The total resistant (with scale from 0 to 2) $F_{2}$ plants were 61 and susceptible (with scale from 2 to 5) 180 . The segregation of resistance and susceptibility perfectly fitted 1:3 ratio $\left(\chi^{2}=0.0124\right.$, $P$-value $\left.=0.911\right)$. The distribution of resistant plants supported that the resistance to late blight pathogen in the present study was governed by single recessive gene.

\section{Distinction of other traits between parents}

Two parents were contrasting phenotypically for fruit type and color (Table 1). Fruit quality and shape of NC 839 were superior to NC 85L. Pedigree analysis of these parents showed that, six parents were common. The coefficient of parentage between them was 0.23 indicating some dissimilarity between these lines. Although variation was found between these lines for morphology and pedigree, polymorphic SSR markers could not be found. Parents were screened by 157 SSR, two COS and 23 M-13 tail SSR primers. Most of them showed monomorphic banding pattern and some of them did not amplify the genomic DNA of these parents. Three systems of fragment analyses, agarose gel, polyacrylamide gel and capillary gel electrophoresis were attempted, which could not detect any polymorphism indicating similarity between these parents for SSR loci.

\section{RAPD analysis}

Out of 197 RAPD primers used to screen parental lines, 34 RAPD primers (17.26\%) were found polymorphic (Table 2). A total of 176 bands with maximum band size of $1500 \mathrm{bp}$ and minimum band size of $100 \mathrm{bp}$ were amplified using 34 primers. Among these bands, 84 were found polymorphic between parents. Average number of bands per polymorphic RAPD primers was 4, ranging from 2 to 8 bands. The number of polymorphic bands ranged from 1 to 4 with an average of 2 . All these 34 polymorphic RAPD primers were used to screen the resistant and susceptible bulks.

Table 2. RAPD primers polymorphic between resistant and susceptible parents of NC $08135 \mathrm{~F}_{2}$ population of tomato screened for late blight resistance

\begin{tabular}{|c|c|c|c|c|c|c|c|c|}
\hline \multirow[t]{2}{*}{ Primer } & \multirow[t]{2}{*}{ Sequence } & \multirow[t]{2}{*}{$\% \mathrm{GC}$} & \multirow{2}{*}{$\begin{array}{l}\text { Amplified } \\
\text { bands }\end{array}$} & \multicolumn{2}{|c|}{ Band size, bp } & \multirow{2}{*}{$\begin{array}{l}\text { Polymor } \\
\text { phic } \\
\text { band }\end{array}$} & \multirow{2}{*}{$\begin{array}{l}\% \\
\text { polymorp } \\
\text { hic }\end{array}$} & \multirow[t]{2}{*}{ Tm } \\
\hline & & & & Max & Min & & & \\
\hline MRTOMR-001 & TCGAGCACT & 50 & 2 & 450 & 400 & 1 & 50 & 30 \\
\hline MRTOMR-003 & AGGGGCTGC & 70 & 5 & 600 & 150 & 1 & 20 & 34 \\
\hline MRTOMR-014 & CGTCTCCAG & 70 & 7 & 600 & 150 & 3 & 43 & 34 \\
\hline MRTOMR-022 & $\mathrm{AGGGCCAGC}$ & 80 & 8 & 1000 & 100 & 6 & 75 & 36 \\
\hline MRTOMR-023 & GACCACGAA & 60 & 3 & 650 & 100 & 2 & 67 & 32 \\
\hline MRTOMR-026 & AGGCACCGT & 60 & 5 & 1000 & 300 & 3 & 60 & 32 \\
\hline MRTOMR-027 & CCTGATGCA & 50 & 3 & 650 & 200 & 3 & 100 & 30 \\
\hline MRTOMR-029 & GCCATACGG & 70 & 2 & 900 & 650 & 2 & 100 & 34 \\
\hline MRTOMR-031 & GGACGTCGC & 80 & 5 & 600 & 200 & 2 & 40 & 36 \\
\hline MRTOMR-033 & GCTCGCGGC & 90 & 5 & 1000 & 150 & 2 & 40 & 38 \\
\hline MRTOMR-038 & TACCTTCGCC & 60 & 6 & 1100 & 150 & 3 & 50 & 32 \\
\hline MRTOMR-039 & $\mathrm{CAGCACCACC}$ & 70 & 7 & 650 & 100 & 3 & 43 & 34 \\
\hline MRTOMR-040 & CAGTCCGCG & 70 & 3 & 500 & 180 & 1 & 33 & 34 \\
\hline MRTOMR-046 & CCATGCGCTA & 60 & 5 & 600 & 100 & 4 & 80 & 32 \\
\hline MRTOMR-063 & CGAGTGACC & 60 & 6 & 550 & 100 & 2 & 33 & 32 \\
\hline MRTOMR-078 & TGCCATGTG & 60 & 4 & 700 & 200 & 1 & 25 & 32 \\
\hline MRTOMR-100 & GACGGCCCCA & 80 & 7 & 1500 & 200 & 3 & 43 & 45 \\
\hline MRTOMR-110 & ATGACGACCT & 50 & 3 & 800 & 400 & 1 & 33 & 31 \\
\hline MRTOMR-112 & CATACACCTC & 50 & 4 & 1500 & 650 & 2 & 50 & 25 \\
\hline
\end{tabular}


Bal K. Joshi et al/RAPD Markers Linked to Late.......

\begin{tabular}{l|l|l|l|l|l|l|l|l}
\hline MRTOMR-117 & CCGAACAATC & 50 & 6 & 950 & 300 & 5 & 83 & 28 \\
MRTOMR-118 & TGCTTGGGGG & 70 & 4 & 1500 & 500 & 3 & 75 & 39 \\
MRTOMR-121 & GGCGTCGTAA & 60 & 3 & 1100 & 550 & 2 & 67 & 36 \\
MRTOMR-128 & AGACCCGGTC & 70 & 3 & 600 & 300 & 1 & 33 & 38 \\
MRTOMR-130 & AGGTCTCTCG & 60 & 3 & 700 & 250 & 1 & 33 & 32 \\
MRTOMR-133 & TTCAGCCACA & 50 & 3 & 900 & 300 & 2 & 67 & 32 \\
MRTOMR-140 & TGCCAACGCC & 70 & 5 & 800 & 250 & 1 & 20 & 42 \\
MRTOMR-141 & CATTGGTGCT & 50 & 2 & 900 & 450 & 1 & 50 & 31 \\
MRTOMR-142 & TTGCGCTTGT & 50 & 2 & 800 & 400 & 1 & 50 & 37 \\
MRTOMR-146 & CGTTACCGGG & 70 & 5 & 2000 & 450 & 2 & 40 & 35 \\
MRTOMR-161 & TGTCTCCCTG & 60 & 5 & 1500 & 700 & 1 & 20 & 32 \\
MRTOMR-171 & GAGGCCAGCG & 80 & 4 & 700 & 200 & 1 & 25 & 43 \\
MRTOMR-178 & GCCATCCGAA & 60 & 2 & 800 & 650 & 1 & 50 & 35 \\
MRTOMR-181 & CATGCGCTCC & 70 & 3 & 800 & 400 & 1 & 33 & 39 \\
OPK6 & CACCTTTCCC & 60 & 4 & 1000 & 600 & 1 & 25 & 31 \\
PH72 & GAGCACGGGA & 70 & 4 & 600 & 250 & 1 & 25 & 39 \\
& & & & & & & & \\
\hline
\end{tabular}

bp = base pair. Tm = Melting temperature

Table 3. RAPD markers polymorphic between resistance and susceptible bulks of tomato to late blight

\begin{tabular}{llllllll}
\hline Primer & $\begin{array}{l}\text { Amplified } \\
\text { bands }\end{array}$ & $\begin{array}{l}\text { Size, bp } \\
\text { Max }\end{array}$ & Min & $\begin{array}{l}\text { Polymorphic } \\
\text { Between } \\
\text { parents }\end{array}$ & $\begin{array}{l}\text { Between } \\
\text { bulks }\end{array}$ & $\begin{array}{l}\text { \% Polymorphic } \\
\text { petweents }\end{array}$ & $\begin{array}{l}\text { Between } \\
\text { bulks }\end{array}$ \\
\hline MRTOMR-014 & 7 & 1500 & 300 & 3 & 2 & 43 & 29 \\
MRTOMR-022 & 7 & 1200 & 300 & 1 & 0 & 14 & 0 \\
MRTOMR-026 & 7 & 1500 & 250 & 1 & 2 & 14 & 29 \\
MRTOMR-031 & 7 & 2000 & 450 & 3 & 1 & 43 & 14 \\
MRTOMR-038 & 4 & 1500 & 300 & 2 & 1 & 50 & 25 \\
MRTOMR-040 & 10 & 1600 & 280 & 4 & 5 & 40 & 50 \\
MRTOMR-046 & 9 & 2000 & 100 & 6 & 5 & 67 & 56 \\
MRTOMR-050 & 4 & 1000 & 400 & 1 & 0 & 25 & 0 \\
MRTOMR-063 & 11 & 1500 & 150 & 2 & 1 & 18 & 9 \\
MRTOMR-076 & 6 & 1500 & 350 & 1 & 2 & 17 & 33 \\
MRTOMR-110 & 6 & 1200 & 180 & 1 & 0 & 17 & 0 \\
MRTOMR-112 & 5 & 1200 & 300 & 1 & 0 & 20 & 0 \\
MRTOMR-121 & 6 & 100 & 380 & 2 & 0 & 33 & 0 \\
MRTOMR-130 & 4 & 750 & 200 & 1 & 0 & 25 & 0 \\
MRTOMR-146 & 9 & 1500 & 250 & 4 & 4 & 44 & 44 \\
MRTOMR-147 & 3 & 900 & 500 & 2 & 0 & 67 & 0 \\
\hline
\end{tabular}

RAPD markers and bulked segregant analysis

Sixteen RAPD primers (47\%) out of 34 were polymorphic between resistant and susceptible bulks of late blight
(Table 3). A total of 105 RAPD bands were observed among four DNA samples from two parents and two bulks. Total polymorphic bands between parents (RP 
and SP) and between bulks (RB and SB) were 35 and 23 respectively. On an average, each primer amplified 7 loci. Average polymorphic bands per primer for parental lines was 2 and for bulks 1 . The largest band size was of $2000 \mathrm{bp}$ and smallest was of $100 \mathrm{bp}$. The polymorphism shown by MRTOMR-046 was the largest (Table 2). The bands generated by MRTOMR147 were mostly polymorphic between parents but none of these bands could distinguish the bulks. Four RAPD primers, namely MRTOMR-026, MRTOMR-031, MRTOMR-038 and MRTOMR-046 were identified as

A.

MRTOMR-026

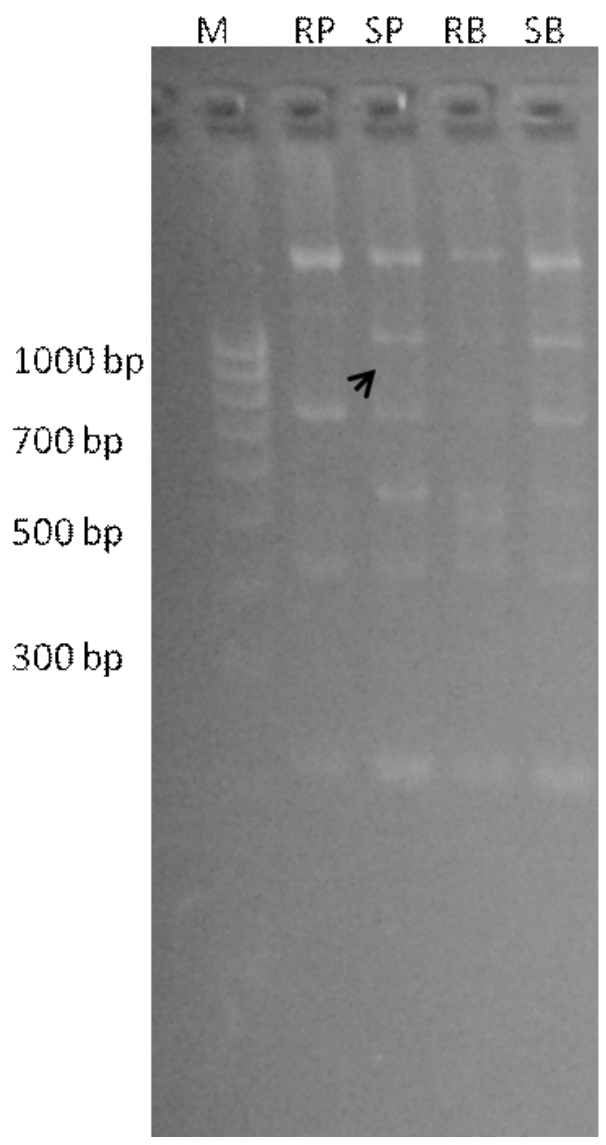

linked markers to loci related to disease reaction (Table 4). Among those, two were linked to susceptibility (Figure 3) and two to resistance (Figure 4). The bands size of 1100 bp amplified by MRTOMR-026 and 800 bp amplified by MRTOMR-046 were found only in susceptible parent i.e. NC 839 and susceptible bulk (SB). Other two primers, MRTOMR-031 and MRTOMR038 produced 550 bp and 1100 bp sized bands respectively that were present only in resistant parent (RP) i.e. NC 085L and resistant bulk (RB).

B. MRTOMR-046

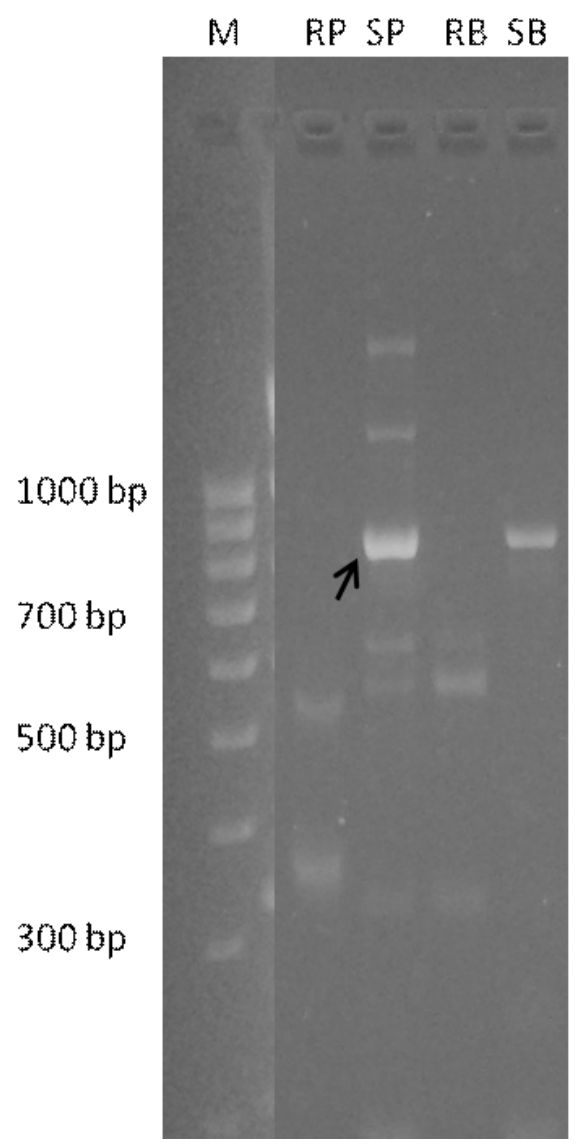

Fig. 3. Electrophoretic pattern of DNA fragments generated by RAPD marker (A. MRTOMR-026, B. MRTOMR-046). Polymorphic band (i.e. linked to susceptible) between parents and between resistant and susceptible bulks are indicated by arrow. RP = Resistant parent, NC 085L. SP = Susceptible parent, NC 839. RB = Resistant bulk. SP = Susceptible bulk. $\mathrm{M}=$ Marker 
Bal K. Joshi et al/RAPD Markers Linked to Late.......

Table 4. Polymorphic bands of RAPD markers linked to either resistance or susceptible conferring genes in tomato to late blight

\begin{tabular}{|c|c|c|c|c|c|c|c|}
\hline Name & PBN & Size, bp & $\mathrm{RP}$ & SP & $\mathrm{RB}$ & SB & Marker type \\
\hline \multirow[t]{2}{*}{ MRTOMR-026 } & 2 & 1100 & 0 & 1 & 0 & 1 & $\mathrm{~N}$ \\
\hline & 5 & 500 & 0 & 0 & 1 & 0 & - \\
\hline \multirow[t]{2}{*}{ MRTOMR-031 } & 3 & 1200 & 1 & 0 & 0 & 0 & - \\
\hline & 6 & 550 & 1 & 0 & 1 & 0 & $\mathrm{P}$ \\
\hline \multirow[t]{2}{*}{ MRTOMR-038 } & 2 & 1100 & 1 & 0 & 1 & 0 & $\mathrm{P}$ \\
\hline & 3 & 750 & 0 & 1 & 1 & 1 & - \\
\hline \multirow[t]{9}{*}{ MRTOMR-046 } & 1 & 2000 & 0 & 1 & 0 & 0 & - \\
\hline & 2 & 1200 & 0 & 1 & 0 & 0 & - \\
\hline & 3 & 800 & 0 & 1 & 0 & 1 & $\mathrm{~N}$ \\
\hline & 4 & 650 & 0 & 1 & 1 & 0 & - \\
\hline & 5 & 600 & 0 & 1 & 1 & 0 & - \\
\hline & 6 & 550 & 1 & 0 & 0 & 0 & - \\
\hline & 7 & 380 & 1 & 0 & 0 & 0 & - \\
\hline & 8 & 350 & 0 & 1 & 1 & 0 & - \\
\hline & 9 & 100 & 0 & 1 & 0 & 1 & - \\
\hline
\end{tabular}

PBN = Polymorphic band number. $\mathrm{RP}=$ Resistant parent $(\mathrm{NC}$ 085LW). SP = Susceptible parent (NC 839-2). RB = Resistant bulk. $\mathrm{SB}=$ Susceptible bulk. $\mathrm{P}=$ Positive. $\mathrm{N}=$ Negative. 1 = Presence. $0=$ Absence. Bold band size is specific marker band linked to either resistance or susceptible genes to late blight of tomato

A.

MRTOMR-031

M RP SP RE SB

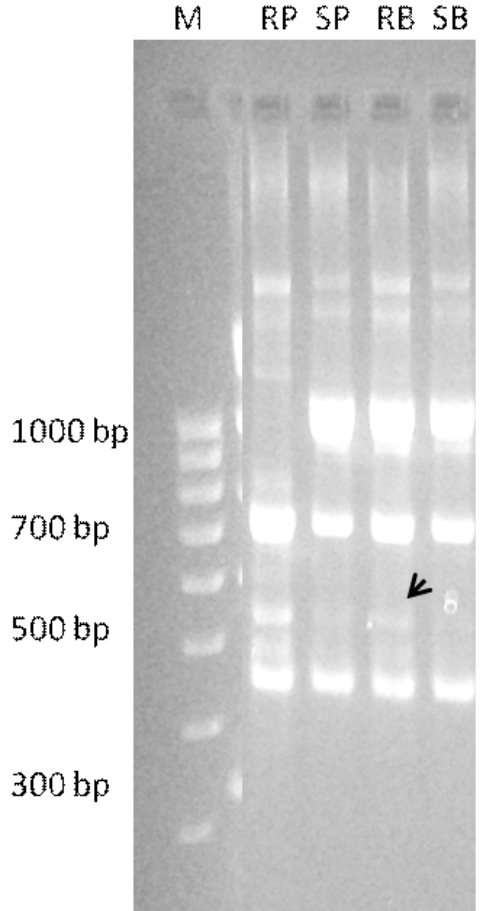

B.

MRTOMOR-O38

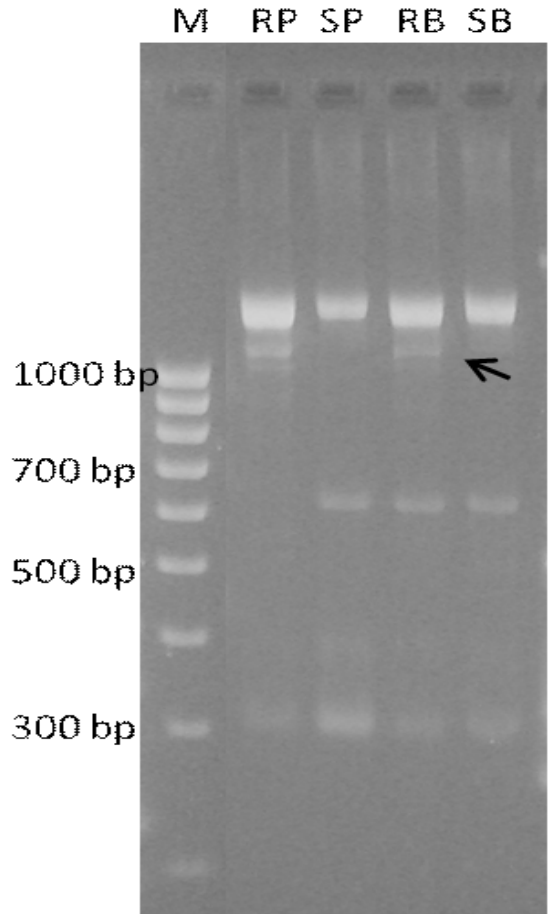

Fig. 4. Electrophoretic pattern of DNA fragments generated by RAPD markers (A. MRTOMR-031, B. MRTOMR-038). Polymorphic band (i.e. linked to resistance) between parents and between resistant and susceptible bulks are indicated by arrow. RP = Resistant parent, NC 085L. SP = Susceptible parent, NC 839. RB = Resistant bulk. SP = Susceptible bulk. $\mathrm{M}=$ Marker 
Eleven primers were found to have bands that were unlinked to the loci. These primers distinguished only parents and not the bulks, therefore, defined as

A

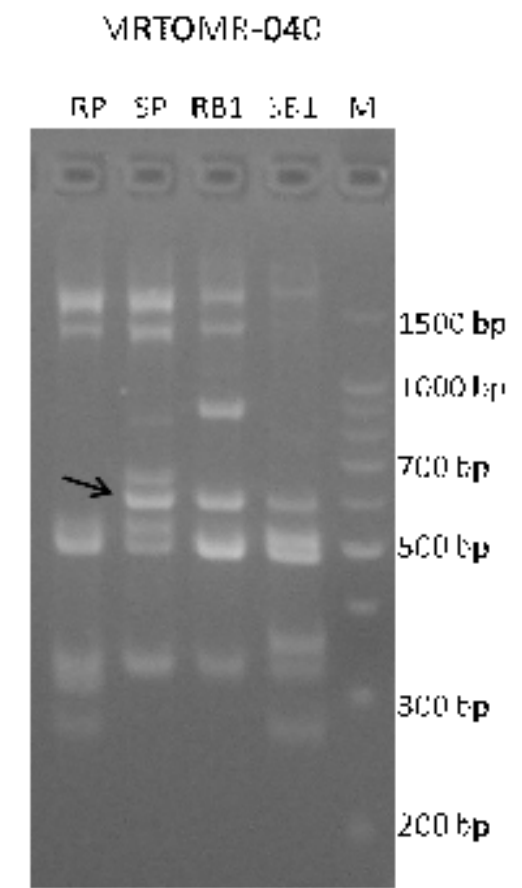

unlinked markers (Figure 5A). The amplified bands of eight RAPD primers were only found in bulks but not in either parent (Fig. 5B).

B.

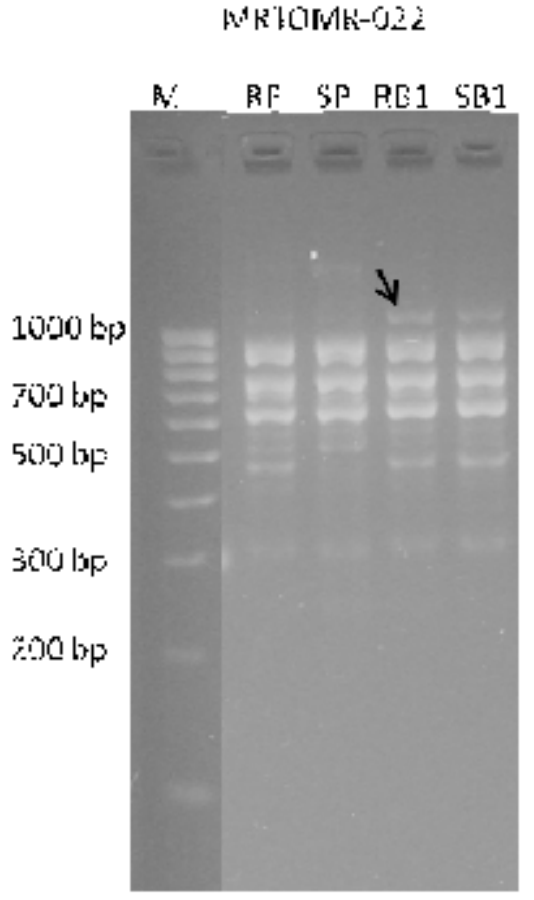

Fig. 5. A. RAPD marker (MRTOMR-040) showing polymorphic band (indicated by arrow) only to parents, i.e. band with unlinked loci. B. RAPD marker (MRTOMR-022) showing band (indicated by arrow) only in two bulks. RP = Resistant parent, NC 085L. SP = Susceptible parent, NC 839. RB = Resistant bulk. SP = Susceptible bulk. $\mathrm{M}=$ Marker

Inheritance study of late blight using $241 \mathrm{~F}_{2}$ individuals showed that late blight resistance was governed by partial recessive gene. Similar result was also reported by Elsayed (2010). He also reported that resistance to late blight was controlled by partial recessive gene. In his study he used NC 1 CELBR and NC 2 CELBR as resistant parents to late blight having $P h-2$ and $P h-3$ genes respectively. Among the $\mathrm{Ph}$ genes resistant to late blight in tomato, $\mathrm{Ph}-2$ and $\mathrm{Ph}-3$ are partially dominant genes (Foolad et al. 2008). In our study, resistant parent, NC 85L also has $P h-2$ and $P h-3$ genes, derived from L3707 and Ritcher's wild tomato, respectively. Different results on the inheritance of late blight might be mainly due to different environments and isolates. The expressions of $\mathrm{Ph}-2$ gene has been reported to be dependent on environmental conditions, crop physiological stage and the pathogen isolate (Moreau et al. 1998). $\mathrm{Ph}-3$, though superior to $\mathrm{Ph}-2$ does not exhibit strong resistance to some isolates (Foolad et al. 2008).

Two RAPD markers linked to resistant allele and two RAPD markers linked to susceptible allele were identified based on the field screening of $\mathrm{F}_{2}$ population by 197 RAPD primers,. Through the bulking of two extreme phenotypes of $\mathrm{F}_{2}$ population it was possible to rapidly tag the markers associated with chromosomal segment that has a role on reaction to late blight pathogen. With BSA technique consisting eight individuals in each bulk, four primers gave different band sizes that were found to be linked to late blight resistance. Chunwongse et al. (2002) identified AFLP marker linked to $P h-3$ gene using BSA and Qiu et al. (2009) identified one RAPD marker which was at distance of $5.8 \mathrm{cM}$ from the target region of late blight resistance. 
The probability of declaring an unlinked polymorphic marker linked to a gene is related with the size of the bulk. Both types of population and the markers should be considered during preparing the bulks (Michelmore et al. 1991). If the size of bulks is small, the frequency of false positives will increase. Michelmore et al. (1991) suggested that, few individuals per bulk were enough to identify the linked markers. The probability of finding an independent marker linked to the gene with bulks size of $n$ is reported to be $2(1 / 4)^{\mathrm{n}}\left[1-(1 / 4)^{\mathrm{n}}\right]$ (Michelmore et al. 1991). Eight individuals were used and based on this formula, the proportion of false positives is about $3 \times 10^{-5}$.

In principle, BSA and NIL are related and many advantages of BSA over NIL are discussed by Michelmore et al. (1991). Tagging of resistance gene using BSA is very fast which facilitates to screen new alleles of resistance for a particular disease. This is important because resistant gene once tagged may not be effective for a long time either because of recombination in the host genome or mutation in the pathogen. The BSA approach is also considered useful to fill the gaps in the maps.

Two parental lines used in this study are closely related to each other and SSR screening showed similar result. However, some RAPD markers distinguished these parents. RAPD is multilocus-marker therefore some primers identified here might be from the overlap regions of the chromosome. For example, MRTOMR026 produced polymorphic band size of $1100 \mathrm{bp}$ between bulks' band and MRTOMR-046 produced polymorphic 800 bp band. The band produced by MRTOMR-046 might be the part of the band generated by MRTOMR-026. These linkages should be verified by mapping the markers. Sequence of amplified region would help if they were from the same region and could be Blast searched in the web to see the similarity and location in the chromosome. A number of disadvantages associated with RAPD, for example, including annealing in multiple sites, dominant nature, sensitive to reaction conditions may limit its use directly in MAS. Therefore, candidate RAPD marker is generally converted to co-dominant SCAR or CAPS markers that are more useful for MAS (Chague et al. 1996).

BSA has been used in a number of crop species to tag various traits including quantitative traits. After identifying useful markers by BSA in tomato, MAS is now possible to apply during the selection of resistance to verticillium wilt, tomato spotted wilt virus, root-knot nematodes, powdery mildew, and fusarium wilt. De Giovanni et al. (2004) identified RAPD marker linked to the ol-2 gene which is resistant to powdery mildew. A single RAPD marker, OPU ${ }_{31500}$ was detected in the susceptible bulk and converted to a CAPS marker. The distance between marker and ol-2 gene was also estimated through linkage analysis. Czech et al. (2003) have used MAS for developing TSWV resistant tomato lines using PCR markers. Smiech et al. (2000) used BSA in $\mathrm{F}_{2}$ segregating population and found five primers that distinguished resistant and susceptible bulks.

In the present study, the disease scores were used that were based on the natural infestation. Different levels of infestation rate were observed in $\mathrm{F}_{2}$ population which indicated that inoculum pressure was enough to screen the population. Use of natural inocula saves cost and time. Screening of target population in target environment can be more successful in the long run to get durable resistant genotypes. Use of hot spot (area naturally favorable for pathogen development) for specific disease helps to increase disease pressure and is cost effective way of resistance breeding and particularly useful in horizontal resistance breeding. Horizontal resistance system is generally considered suitable for long term cultivation of resistance varieties. Spaner et al. (1998) mapped loci affecting resistance to powdery mildew, leaf rust, stem rust, scald and net blotch in barley using field-scored data of disease severity under natural infestation. Naturally infested population had been used in a number of crop species. For example, two QTLs for glume botch resistance in wheat were identified using composite interval mapping from naturally inoculated populations (Schnurbusch et al. 2003). Spaner et al. (1998) mapped the loci affecting resistance to powdery mildew, leaf rust, stem rust, scald and net blotch in barley using field-scored data of disease severity under natural infestation. Natural infestation was also used by Frei et al. (2005) to identify QTLs resistance to thrips in common bean.

Four potential RADP primers associated with reaction to late blight resistance in tomato were identified. Two primers gave positive bands in resistant genotypes so those primers could be very useful in MAS. Because 
of low reproducibility and dominant nature of RAPD, these markers should be converted to co-dominant SCAR markers to identify the tightly linked markers, so that MAS could be applied using a single marker. MAS is cost effective and more precise, because it does not require pathological evaluation and genotyping can be done at any growth stage. Identified markers linked to resistance may also have utility in gene pyramiding.

\section{References}

Brouwer, D.J., E.S. Jones and D.A.S. Clair. 2004. QTL analysis of quantitative resistance to Phytophthora infestans (late blight) in tomato and comparisons with potato. Genome 47(3):475-492.

Chagué, V., J.C. Mercier, M. Guénard, A. Courcel and F. Vedel. 1996. Identification and mapping on chromosome 9 of RAPD markers linked to $S w-5$ in tomato by bulked segregant analysis. Theoretical and Applied Genetics. 92(8):1045-1051.

Chunwongse, J., C. Chunwongse, L. Black and P. Hanson. 2002. Molecular mapping of the $P h-3$ gene for late blight resistance in tomato. Journal of Horticulture Science and Biotechnology 77(3):281-286.

Czech, A.S., M. Szklarczyk, Z. Gajewski, E. Zukowska, B. Michalik, T. Kobylko and K. Strzalka. 2003. Selection of tomato plants resistant to a local Polish isolate of tomato spotted wilt virus (TSWV). Journal of Applied Genetics 44(4):473-480.

Danesh, D., S. Aarons, G.E. McGill and N.D. Young. 1994. Genetic dissection of oligogenic resistance to bacterial wilt in tomato. Molecular PlantMicrobe Interaction 7(4):464-471.

Davis, R.M., G. Hamilton, W.T. Lanini, T.H. Spreen and C. Osteen. 2000. The importance of pesticides and other pest management practices in U.S. tomato production. USDA, NAPIAR.

De Giovanni, C., P. Dell’Orco, A. Bruno, F. Ciccarese, C. Lotti and L. Ricciardi. 2004. Identification of PCR-based markers (RAPD, AFLP) linked to a novel powdery mildew resistance gene (ol-2) in tomato. Plant Science 166(1):41-48.

Elsayed, A.Y.A.M. 2010. Inheritance of resistance to tomato late blight in a population of Solanum lycopersicum x Solanum habrochaites. Available at http://twas.assaf.org.za:8080/jspui/handle/ 123456789/12 (verified 6 April 2011).

FAOSTAT. 2010. Food and Agriculture Organization of the United Nations. Available at http:// faostat.fao.org/site/339/default.aspx (verified 25 June 2010).

Foolad, M., H. Merk and H. Ashrafi. 2008. Genetics, genomics and breeding of late blight and early blight resistance in tomato. Critical Review in Plant Sciences 27(2):75-107.

Frei, A., M.W. Blair, C. Cardona, S.E. Beebe, H. Gu and S. Dorn. 2005. QTL mapping of resistance to Thrips palmi Karny in common bean. Crop Science 45(1):379-387.

Fry, W.E. and S.B. Goodwin. 1997. Resurgence of the Irish potato famine fungus. Bioscience 47(6):363371.

Fulton, T.M., J. Chunwongse and S.D. Tanksley. 1995. Microprep protocol for extraction of DNA from tomato and other herbaceous plants. Plant Molecular Biology Reporter 13(3):207-209.

Gardner, R.G. and D.R. Panthee. 2010a. Plum Regal freshmarket plum tomato hybrid and its parents, NC 25P and NC 30P. HortScience 45(5):824-825.

Gardner, R.G. and D.R. Panthee. 2010b. NC 1 CELBR and NC 2 CELBR: Early blight and late blightresistant fresh market tomato breeding lines. HortScience 45(6):975-976.

Giovannoni, J.J., R.A. Wing, M.W. Ganal and S.D. Tanksley. 1991. Isolation of molecular markers from specific chromosomal intervals using DNA pools from existing mapping populations. Nucleic Acid Research 19(23):6553-6558.

Mackay, I.J. and P.D.S. Caligari. 2000. Efficiencies of $F_{2}$ and backcross generations for bulked segregant analysis using dominant markers. Crop Science 40:626-630.

Michelmore, R.W., I. Paran and R.V. Kesseli. 1991. Identification of markers linked to diseaseresistance genes by bulked segregant analysis: A rapid method to detect markers in specific genomic regions by using segregating populations. Proceedings of the National Academic of Sciences 88(21):9828-9832.

Moreau, P., P. Thoquet, J. Olivier, H. Laterrot and N. Grimsley. 1998. Genetic mapping of $P h$-2, a single locus controlling partial resistance to Phytophthora infestans in tomato. Molecular Plant-Microbe Interaction 11(4):259-269.

Panthee, D.R. and F. Chen. 2010. Genomics of fungal disease resistance in tomato. Current Genomics 11(1):30-39.

Panthee, D.R. and R.G. Gardner. 2010. Mountain Merit: A late blight-resistant large-fruited tomato hybrid. HortScience 45(10):1547-1548.

Qiu, Y.P., H.T. Li, Z. Zhang and Q.D. Zou. 2009. RAPD marker of the resistant gene $P h-3$ for tomato late blight. Acta Horticulturae Sinica 36(8):1227-1232.

Quarrie, S.A., V. Lazic-Jancic, D. Kovacevic, A. Steed and S. Pekic. 1999. Bulk segregant analysis with molecular markers and its use for improving drought resistance in maize. Journal of Experimental Botany 50(337):1299-1306. 
Bal K. Joshi et al/RAPD Markers Linked to Late.......

Schnurbusch, T., S. Paillard, D. Fossati, M. Messmer, G. Schachermayr, M. Winzeler and B. Keller. 2003. Detection of QTLs for Stagonospora glume blotch resistance in Swiss winter wheat. Theoretical and Applied Genetics 107(7):1226-1234.

Smiech, M., Z. Rusinowski, S. Malepszy and K. Niemirowicz-Szczytt. 2000. New RAPD markers of tomato spotted wilt virus (TSWV) resistance in Lycopersicon esculentum Mill. Acta Physiologiae Plantarum 22(3):299-303.

Spaner, D., L.P. Shugar, T.M. Choo, I. Falak, K.G. Briggs, W.G. Legge, D.E. Falk, S.E. Ullrich, N.A. Tinker and B.J. Steffenson. 1998. Mapping of disease resistance loci in barley on the basis of visual assessment of naturally occurring symptoms. Crop Science 38(3):843-850.
Stevens, M.R., E.M. Lamb and D.D. Rhoads. 1995. Mapping the $S w-5$ locus for tomato spotted wilt virus resistance in tomatoes using RAPD and RFLP analyses. Theoretical and Applied Genetics 90(3):451-456.

Tinker, N.A. and D.E. Mather. 1993. KIN: Software for computing kinship coefficients. Journal of Heredity 84:238.

Tu, J.C. and V. Poysa. 1990. A brushing method of inoculation for screening tomato seedlings for resistance to Septoria lycopersici. Plant Diseases 74:294-297.

Winstead, N.N. and A. Kelman. 1952. Inoculation technique for evaluating resistance to Pseudomonas solanacearum. Phytopathology 42:628-634. 
Nepal Journal of Science and Technology Vol. 14, No. 1 (2013) 1-14 